Journal of Tropical Ecology

http://journals.cambridge.org/TRO

Additional services for Journal of Tropical Ecology:

Email alerts: Click here

Subscriptions: Click here

Commercial reprints: Click here

Terms of use : $\underline{\text { Click here }}$

\title{
Structurally complex farms support high avian functional diversity in tropical montane Ethiopia
}

Aaron D. Gove, Kristoffer Hylander, Sileshi Nemomissa, Anteneh Shimelis and Woldeyohannes Enkossa

Journal of Tropical Ecology / Volume 29 / Issue 02 / March 2013, pp 87 - 97

DOI: 10.1017/S0266467413000023, Published online: 11 February 2013

Link to this article: http://journals.cambridge.org/abstract S0266467413000023

How to cite this article:

Aaron D. Gove, Kristoffer Hylander, Sileshi Nemomissa, Anteneh Shimelis and Woldeyohannes Enkossa (2013). Structurally complex farms support high avian functional diversity in tropical montane Ethiopia. Journal of Tropical Ecology, 29, pp 87-97 doi:10.1017/S0266467413000023

Request Permissions : $\underline{\text { Click here }}$ 


\title{
Structurally complex farms support high avian functional diversity in tropical montane Ethiopia
}

\author{
Aaron D. Gove*,1, Kristoffer Hylander*, Sileshi Nemomissa $\dagger$, Anteneh Shimelis $\nmid$ and \\ Woldeyohannes Enkossa $\ddagger$
}

\author{
* Department of Botany, Stockholm University, SE-10691 Stockholm, Sweden \\ $\dagger$ Plant Biology and Biodiversity Management Programme Unit, P.O. Box 3434, Addis Ababa University, Addis Ababa, Ethiopia \\ $\ddagger$ Department of Biology, Mettu College of Teachers Education, PO Box 44, Oromia, Ethiopia \\ (Received 28 February 2012; revised 12 January 2013; accepted 13 January 2013; first published online 11 February 2013)
}

\begin{abstract}
Of all feeding guilds, understorey insectivores are thought to be most sensitive to disturbance and forest conversion. We compared the composition of bird feeding guilds in tropical forest fragments with adjacent agroecosystems in a montane region of south-west Ethiopia. We used a series of point counts to survey birds in 19 agriculture and 19 forest sites and recorded tree species within each farm across an area of $40 \times 35 \mathrm{~km}$. Insectivores $(\sim 17$ spp. per plot), frugivores ( $\sim 3$ spp. per plot) and omnivores ( $\sim 5$ spp. per plot) maintained species density across habitats, while granivores and nectarivores increased in the agricultural sites by factors of 7 and 3 respectively. Species accumulation curves of each guild were equal or steeper in agriculture, suggesting that agricultural and forest landscapes were equally heterogeneous for all bird guilds. Counter to most published studies, we found no decline in insectivore species richness with forest conversion. However, species composition differed between the two habitats, with certain forest specialists replaced by other species within each feeding guild. We suggest that the lack of difference in insectivorous species numbers between forest and agriculture in this region is due to the benign nature of the agricultural habitat, but also due to a regional species pool which contains many bird species which are adapted to open habitats.
\end{abstract}

Key Words: Africa, agro-ecosystem, avifauna, feeding guilds, species pool, remnant trees

\section{INTRODUCTION}

Conversion of tropical forests to agriculture often leads to a decrease in bird species richness with only a subset of the forest species surviving in agricultural habitats (Dunn 2004a). Bird feeding guilds may vary in sensitivity to habitat alteration and the consequent negative responses of insectivorous guilds have often been emphasized (Canaday 1996, Şekercioglu 2002a, Şekercioglu et al. 2002, Stouffer \& Bierregaard 1995, Tscharntke et al. 2008). Agricultural landscapes may vary in their capacity to support forest birds indirectly through buffering edge effects, providing a permeable matrix or directly through provision of habitat.

Structurally complex agriculture is likely to support a broader range of bird species. For example, Clough et al.

\footnotetext{
${ }^{1}$ Corresponding author. Current address: Department of Environment and Agriculture, Curtin University, Perth, WA, Australia. Email: a.gove@curtin.edu.au
}

(2009), found that the conversion to structurally complex shaded cocoa plantations did not disproportionately affect insectivorous birds, probably due to a high density of insect prey maintained by high tree densities. Agroecosystems of Africa, including those of Ethiopia, can often be complex with a diversity of indigenous and introduced crops and, in certain regions, a high density of scattered trees which may limit losses of sensitive guilds such as insectivores (Fischer et al. 2010, Gove et al. 2005, Manning et al. 2006). At a broader landscape scale, a series of such farms may provide a broad range of habitats and therefore support a large number of bird species when compared with a homogeneous series of farms (Flather 1996).

In Africa, bird species richness in forested regions (especially montane forests) is lower than other regions of the world, and lower than more open habitats such as savannas of Africa (Moreau 1966). Therefore agricultural habitats of Ethiopia will possess more bird species if they are colonized by the relatively rich pool of species 
adapted to open habitats (Harrison \& Cornell 2008, Ricklefs 1987). Connectivity to more open habitats such as savannas, wetlands or even agricultural areas with a longer history may also be an important variable in explaining the assemblage composition and guild structure in a newly disturbed region (Terborgh \& Weske 1969). Hence, farmlands that are both spatially connected to other open habitats and are structurally complex may sustain a guild structure not usually predicted for landscapes converted to agriculture (Harvey et al. 2006).

In this paper we explore a landscape mosaic of agriculture and forest in south-west Ethiopia and determine whether particular Afromontane bird guilds are sensitive to conversion to agriculture and whether overall compositional changes reflect changes in feeding guild structure (Şekercioğlu et al. 2004, Sodhi et al. 2004). We hypothesize that the complex structure of the studied farms combined with a species pool of birds adapted to open habitats will lead to few losses of species diversity, even within particularly sensitive feeding guilds.

\section{METHODS}

\section{Study region and sites}

We conducted the study in a $40 \times 35-\mathrm{km}$ area surrounding the town of Bonga $\left(36^{\circ} 14^{\prime} \mathrm{E}, 7^{\circ} 16^{\prime} \mathrm{N}\right), 450$ $\mathrm{km}$ south-west of Addis Ababa, Ethiopia (Gove et al. 2008). The area's climate is warm tropical with the main rainy season occurring from March to October. Annual average rainfall is approximately $1700 \mathrm{~mm}$ $\mathrm{y}^{-1}$ and dominant vegetation is Afromontane rain forest (Friis et al. 1982) with species such as Sapium ellipticum (Hochst.) Pax (Euphorbiaceae), Schefflera abyssinica (A. Rich.) Harms (Araliaceae) and Millettia ferruginea (Hochst.) Baker (Fabaceae). We recorded 62 tree species in the study. The five most common farmland trees were: Albizia gummifera (J.F. Gmel.) C. A. Sm. (Fabaceae), Sapium ellipticum (Hochst.) Pax (Euphorbiaceae), Cordia africana Lam. (Boraginaceae), Ficus sur Forsskål (Moraceae) and Millettia ferruginea (Hochst.) Baker (Fabaceae), all of which are indigenous forest trees which have been promoted in agriculture. Only two species were introduced (Alangium chinense (Lour.) Harms (Alangiaceae) and Eucalyptus camaldulensis Dehnh. (Myrtaceae)). The landscape is a mosaic of forests and agricultural areas with both large $(>100$ ha) and small ( $<1 \mathrm{ha}$ ) patches of forest and agriculture. Approximately $40 \%$ of the landscape is currently covered with forest (Gove et al. 2008). During the last $50 \mathrm{y}$ for which we have access to aerial photos and satellite imagery (LANDSAT) there has been a slow but steady land conversion to agriculture, with consequent reduction in the size of the forest fragments. Around $50 \%$ of our investigated agricultural areas are situated within areas that have been converted within this time frame. The history of the rest of the landscape is difficult to ascertain due to lack of older aerial photographs. However, even if there may have been fluctuations in forest cover during the last $150 \mathrm{y}$ it is likely that annual crop agriculture is of much more recent origin here than in the central highlands (McCann 1995). We carried out all fieldwork during June-August 2007, during the bird breeding season, when identifying canopy birds from song was easiest.

Farms are made up of a variety of crops, and more than 60 food plants including corn and coffee are grown across these farms which often contain a variety of tree species.

We chose 19 farm sites and 19 forest sites, widely dispersed across the focal landscape, attempting to maximize the variation in coverage of agriculture and forest amongst sites. The sites were chosen from global Landsat images produced in 2000, with 15-m resolution. We separated our sites into farmland and forest as the landscape is clearly defined by these two habitat types, both superficially and by local communities responsible for their management. Sites were separated by at least 2 $\mathrm{km}$ within each habitat category. Altitude ranged from 1700 to $2350 \mathrm{~m}$ asl. We were led to each site using GPS and at each site we established a $100 \times 200-\mathrm{m}$ plot.

\section{Bird surveys and vegetation}

At each farm and forest site, we used 228 -min point counts evenly distributed within the $100 \times 200$-m plot. Three rows of four points, alternating with two rows of five points with the outer points on the margin of the quadrat led to a survey area closer to $150 \times 250 \mathrm{~m}$. Given the small size and high heterogeneity of many farms and forest patches, we employed a relatively dense array of point counts. Each point was sampled once. This was necessary as we could only survey one site per day, due to the wide dispersal of sites and transport by foot, and our aim to samples as many sites as possible within a 3mo field season. Increased, repeated sampling may have increased species richness estimates, but current sampling is sufficient for meaningful comparisons amongst habitat types. We recorded all bird species seen and heard within a 25-m radius. On several occasions we did not complete all 22 point counts (at least 18; usually due to rain). Each site survey was carried out in $1 \mathrm{~d}$ soon after sunrise and lasted approximately $3-4 \mathrm{~h}$.

At each farm site, the $100 \times 200-m$ plot was divided into fifty $20 \times 20$-m subplots in which we recorded density and diameter of all trees $(\mathrm{dbh}>15 \mathrm{~cm})$ and per cent cover of coffee and food plants. Where tree species could not be identified in the field, specimens were taken to the 
National Herbarium of Ethiopia (ETH) for identification and deposited there.

\section{Data analysis}

We classified bird feeding guilds based on Waltert et al. (2005). We further classified the insectivores into subguilds based on strata and feeding behaviour in a similar manner to Waltert et al. (2005) (Appendix 1). Species body weights were taken from Dunning (1992).

For each site we estimated species richness based on the Jackknife 2 estimator which accounts for variability in detection probability across species and habitats (Nichols et al. 1998). Samples were considered to be the individual point counts, with species richness estimated for each site. Analysis was carried out using EstimateS 8 (http://viceroyeeb.uconn.edu/estimates). We used MANOVA to compare species richness across habitats (forest vs. agriculture), using Pilai's trace as our test criterion and after confirming assumptions of normality and sphericity. We performed one MANOVA for primary feeding guilds and another for the insectivorous subguilds.

For each species, we obtained an indicator value for each of the two habitats (agriculture and forest), using the technique of Dufrêne \& Legendre (1997) and including the frequency of occurrence of each species. The approach provides an indicator score for each species based on its fidelity to a single habitat type. We then calculated a preference index by subtracting the indicator value for agriculture from the value for forest. Therefore, species with a negative index suggested a preference for agriculture, while a positive index suggested a preference for forest (Dynesius et al. 2009). We used a general linear model with Gaussian error structure to test for a difference in response to agricultural clearing amongst guilds; the response variable was the indicator value of each species while guild and weight were treated as predictor variables. We used Anosim (Clarke 1993) in a separate analysis for each guild to determine whether species composition of each guild differed between the forest and agriculture habitat. We used Sørensen's index as the measure of dissimilarity and randomized our data 999 times.

We tested for a multivariate correlation between bird species assemblage and tree species assemblage amongst farm sites using a Mantel test. Both bird and tree distance matrices were calculated using Bray-Curtis similarity. We performed tests for the bird assemblage as a whole, and for each bird feeding guild separately.

We used general linear models with Gaussian error structure to understand the variation in species richness of the guilds as it related to variation in measured environmental variables. The independent variables considered for model-inclusion were: tree density, tree species density (which was correlated with species density of forest tree species - a variable excluded from the model), and the proportion of fleshy-fruited trees (in terms of individuals and species). Final model diagnostics confirmed appropriate error structures. The most parsimonious models were selected using a bestsubsets approach based on the Bayesian Information Criterion (Miller 2002).

In order to examine the level of species turnover in each of the guilds and habitats, species accumulation curves were created using EstimateS. Curves were created by randomization of observed data samples, with each site considered a sample. All other analyses were performed in R2.6.1 (http://www.R-project.org).

\section{RESULTS}

No guild declined in species richness with transition to farmland (Figure 1). However, nectarivore and granivore species richness were, respectively, three and seven times higher in farmlands (Figure $1 ; \mathrm{F}_{1,36}=34.6, \mathrm{P}<0.001$, $\mathrm{F}_{1,36}=38.3, \mathrm{P}<0.001$ respectively). Amongst the insectivorous subguilds there were no significant changes in species richness between the two habitats (Pillai's trace $=0.240, \mathrm{~F}_{7,36}=1.35, \mathrm{P}=0.262$ ).

Based on indicator values, habitat preferences differed significantly amongst feeding guilds (Figure $2 \mathrm{a} ; \mathrm{F}_{4,98}=$ 2.94, $\mathrm{P}=0.024)$. Mean index of habitat preference differed from zero for both granivores $\left(\mathrm{t}_{19}=-4.23\right.$, $\mathrm{P}<0.001)$ and nectarivores $\left(\mathrm{t}_{5}=-2.61, \mathrm{P}=0.047\right)$, suggesting significant preferences for the farmland habitat. However, within the insectivorous guild there are many species with strong preference for either agricultural or forest sites (Figure 2a), with the understorey foliage gleaners having the strongest set of preferences (Figure $2 \mathrm{~b}$ ). Body weight had no relationship with habitat preference based on indicator values $\left(\mathrm{F}_{1,96}=\right.$ $0.041, \mathrm{P}=0.842$ ), and had no significant interaction with feeding guild $\left(\mathrm{F}_{9,88}=1.54, \mathrm{P}=0.146\right)$. All guilds differed in species composition between forest and agricultural habitat (ANOSIM statistic $\mathrm{R}=0.057-0.664$, $\mathrm{P}=0.001-0.023)$.

Farms had an average $( \pm$ SD) of $4.3 \pm 8.3$ food plant species per 2-ha plot and a tree density of $4.9 \pm 2.0$ trees $\mathrm{ha}^{-1}$. Amongst the 19 farms, bird species assemblage was correlated with the tree species assemblage (Table 1). Within guilds, species composition of the omnivore and granivore assemblages was correlated with the tree species assemblages (Table 1).

We were able to fit a significant environment-species richness model for two guilds within farmland $(\mathrm{P}<0.05$, Table 2). Nectarivore and insectivore species richness were both correlated with the species richness of trees. Frugivores and omnivores were not associated with any environmental variables including the proportion 


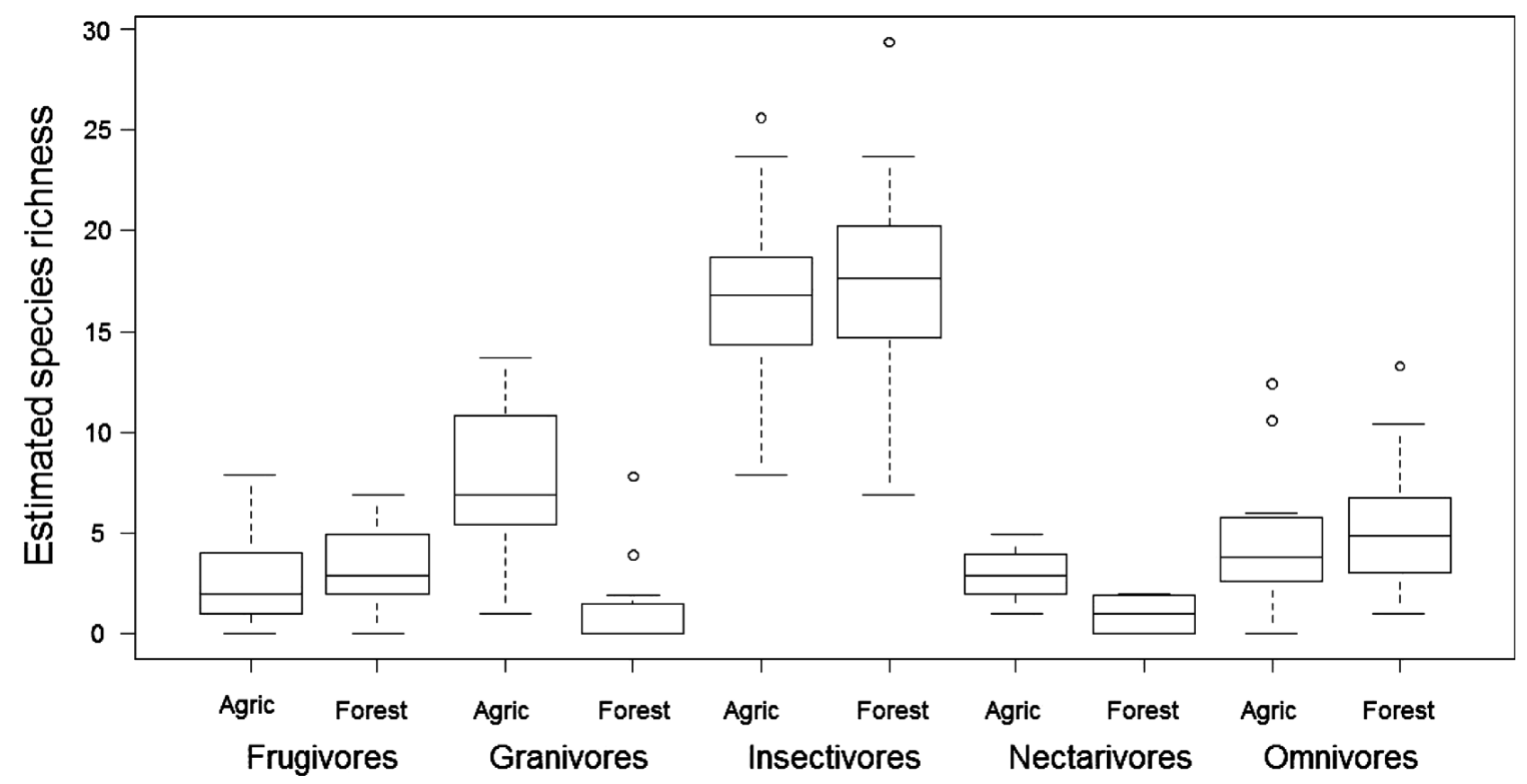

Figure 1. Ethopian tropical montane bird species richness in agricultural and forest habitats, with comparison among feeding guilds. Box plots represent the median value, with extent of box representing the 25 th and 75 th percentiles. Whiskers encompass observations within 1.5 times the extent of the box. Outliers are represented by individual points (Agric $=$ Agricultural plots).

of fleshy-fruited trees, while granivores were negatively correlated with the proportion of fleshy-fruited tree species.

Granivores were the most species-rich guild and nectarivores the least rich. Overall, species accumulated at a faster rate in the agriculture plots than in the forest fragments and overall species richness was higher in agriculture (Figure 3a). Agricultural plots contained 22 more species than forest plots, 14 of which were granivorous species. Omnivores were the only group that was more species rich in the forest (10 versus 8 species). Within most guilds, species accumulation rates were similar in forest and agriculture (Figure 3b), with the strongest exception being the granivores which were almost four times richer in agriculture (Figure 3c). This was also true, but to a lesser extent for the nectarivores which were approximately twice as rich in agriculture.

\section{DISCUSSION}

Here we demonstrate that avian feeding guilds are differentially affected by forest conversion in tropical montane Ethiopia. However effects were not those often emphasized in studies of tropical forest conversion, with instead the largest effects being the promotion of some guilds (nectarivores and granivores) rather than the decline in particular guilds. In terms of number of species, we observed no difference in insectivore occurrence between forests and farm sites and this lack of difference was maintained even when considering subguilds including understorey foragers. This is surprising given that understorey insectivores are considered one of the most sensitive bird guilds (Canaday 1996, Şekercioglu 2002b, Sekercioglu et al. 2002, Stouffer \& Bierregaard 1995, Tscharntke et al. 2008). However, when studying individual species it is evident that some insectivores have a strong association with forests, while others have a clear affiliation to the agricultural landscape (see also Martin et al. 2012). Thus the insectivore guild does respond to a conversion to agriculture, but that response does not lead to an overall decline in insectivore species richness.

While a high density of trees and a diversity of introduced and indigenous food plants can partially explain the species composition of the studied farmland (Gove et al. 2008, Hylander \& Nemomissa 2008, Martin et al. 2012), a complementary explanation is that there is connectivity both in time and space to other open areas - both savannas and areas cultivated for agriculture over long periods. There are thus many birds in the species pool that have evolved in more open areas (savannas in lowlands, alpine areas in the highlands, or wetlands) and/or have adapted to agricultural areas that could colonize forest areas which have been disturbed and converted (Moreau 1966). A further explanation is that African bird species may not be as sensitive to forest conversion due to several thousand years of forest clearance and agrarian activity (Chapman \& Chapman 
a)

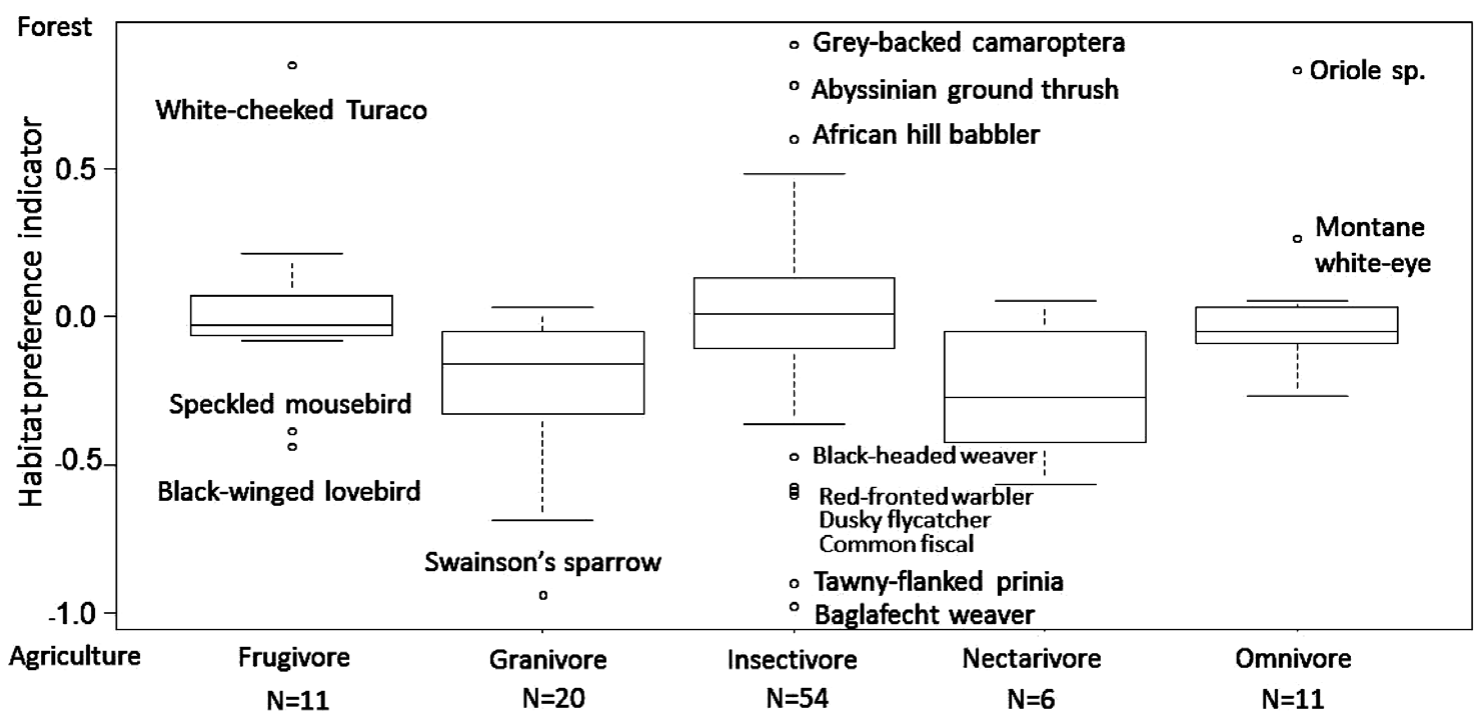

b)

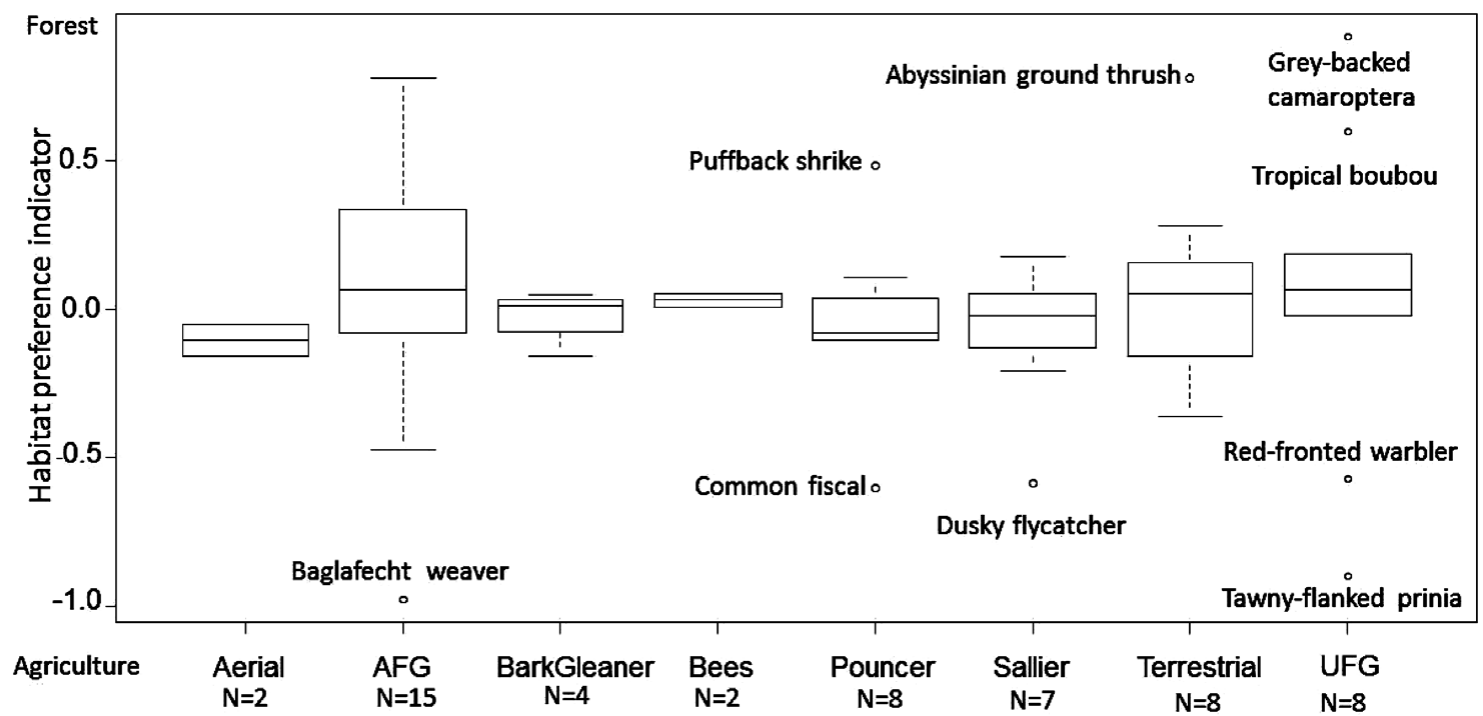

Figure 2. Habitat preferences for bird species of tropical montane Ethiopia. Preferences of species are defined by their Indicator Value. Preference index is the indicator value for agriculture minus indicator value for forest. Positive values suggest a preference for forest, while negative numbers suggest a preference for agriculture. Habitat preference of species within each feeding guild (a). Habitat preference of species within each subguild of insectivores (b). (AFG = Arboreal foliage gleaner; UFG = Understorey foliage gleaner)

1996, Darbyshire et al. 2003, Hamilton et al. 1986) which may have selected African fauna to be more disturbancetolerant than fauna of other regions (Karr 1976). On the other hand, Danielson (1997) has suggested that based on stable ecoclimatic histories, African bird assemblages may be more susceptible to disturbances than other regions, but has been unable to support the suggestion.

The majority of studies documenting declines of insectivorous birds have been carried out in the Neotropics and Asia (Gray et al. 2007) and it is not well understood how broadly these generalizations can be applied. With African bird guilds a lack of response to disturbance or maintenance of species richness in disturbed areas for African insectivores does not appear universal. For instance, Şekercioğlu (2002a), Waltert et al. (2005) and Mulwa et al. (2012) demonstrated negative responses of insectivore species richness or abundance. This suggests that African bird guilds are not necessarily more robust to disturbance than those of other regions and that effects may depend upon the structural diversity of disturbed habitats and their connectivity to bird species adapted to open habitats. It would be interesting to study a longer gradient in agricultural heterogeneity to identify thresholds in tree 
Table 1. Relationship between Ethiopian tropical montane bird assemblages and tree assemblages in agricultural plots. Multivariate correlations between the tree species composition of agriculture sites and the associated bird species composition $(n=19)$ were tested using Mantel tests. $\mathrm{P}$ is based on 1000 randomizations of the observed data.

\begin{tabular}{lcc}
\hline & Mantel's R & $\mathrm{P}$ \\
\hline All species & 0.210 & 0.027 \\
Omnivores & 0.387 & 0.001 \\
Insectivores & 0.065 & 0.258 \\
Granivores & 0.210 & 0.027 \\
Nectarivores & -0.206 & 0.982 \\
Frugivores & 0.064 & 0.241 \\
\hline
\end{tabular}

Table 2. Ethiopian tropical montane bird assemblages in farmland: the response of bird feeding guilds to farm-level habitat variables tested across 19 farms. The response variable considered is the species richness within each feeding guild. Models were established using a minimum subset approach based on minimizing BIC. The table includes the model parameter estimates association with four predictor variables. Tree species is the number of species in each farm plot. 'Propn fleshy individ' is the proportion of individual trees with fleshy fruit, 'Propn fleshy species' is the proportion of tree species in each farm known to produce fleshy fruit.

\begin{tabular}{llcccc}
\hline Tree density & $\begin{array}{c}\text { Tree } \\
\text { species }\end{array}$ & $\begin{array}{c}\text { Propn fleshy } \\
\text { individ. }\end{array}$ & $\begin{array}{c}\text { Propn fleshy } \\
\text { species }\end{array}$ & Rsq (adj) & P \\
\hline Nectarivores & 0.158 & & & 0.27 & 0.013 \\
Granivores & & & -13.9 & 0.144 & 0.061 \\
Insectivores & 0.471 & & & 0.167 & 0.047 \\
Omnivores & & & -3.88 & -0.311 & 0.508 \\
Frugivores & & & 1.56 & -0.053 & 0.755 \\
\hline
\end{tabular}

species density or tree species composition related to species persistence in the agricultural landscape. In Europe a large proportion of species are adapted to open habitats but are threatened by agricultural intensification (Donald et al. 2001). Ethiopia may also possess a bird fauna characteristic of structurally diverse small-scalefarming landscapes which are threatened by agricultural intensification and modernization. This is not unlikely given the high population density and high percentage of land used by people for subsistence agriculture. Another interpretation of the relatively high number of species in our agricultural sites is species-impoverished forest plots. However, we have previously demonstrated that the bird assemblages in the forest and agriculture sites are quite distinct (Gove et al. 2008), and here we describe many bird species that are indicative of forest habitats. With $40 \%$ of the forest still remaining in the landscape, we would expect that we have sampled a forest with some integrity and some level of forest fauna intact (Andrén 1994), but as Moreau (1966) point out the Ethiopian montane forests have a rather depauperate bird fauna even compared with other African montane forest areas. Historical factors may therefore be an important explanation for the species pools (Ricklefs 1987).
What are the consequences of such functional guild stability or change? While we do not demonstrate declines in species richness of any insectivorous guild, we do find changes in the insectivorous assemblage. It would thus be interesting to compare farm sites, which differ in similarity to forests, and ask, for example, whether pest control on insects are different in these sites (Greenberg et al. 2000). Lack of declines in nectarivore species richness and no habitat specialists suggest that bird-dependent pollination on farms is most likely intact. No forestspecialist granivores were identified, however intensive agriculture in other (temperate) parts of the world has led to declines in not only insectivorous and omnivorous species but also granivorous species (Siriwardena et al. 2000). A deeper understanding of how intensification in Ethiopia affects the bird communities and guild structures and ecological functions is important not only from a conservation perspective but also that of ecosystem service and disservices.

Frugivores were expected to have the clearest response to tree species composition through their association with fleshy-fruited trees (Da Silva et al. 1996, Daily et al. 2001, Luck \& Daily 2003). But in our study, frugivore assemblage composition was not correlated with tree composition and frugivores were not favoured by increased density or richness of fleshy-fruited trees. Season and the availability of fruit may have played some role in a lack of association between fleshy-fruited trees: We sampled in the wet season, when bird activity was expected to be highest; however most fruits are expected to be most abundant later in the season, which may explain the lack of correlation in our data. Although body size has been associated with extinction risk in birds (Gaston \& Blackburn 1995) and has implications for ecosystem function (Fischer et al. 2007), we found no strong role of body size in species sensitivity to forest conversion. Body size played little role in the meta-analysis of Gray et al. (2007) of guild responses and like our study, did not demonstrate a guild $\times$ body weight interaction in the response of bird species. We have no indication, for instance, that large frugivores are most likely to decline in agricultural landscapes, and therefore alter dispersal of large-fruited species. However, restriction of particular species to a given habitat may alter dispersal processes.

The heterogeneous structure of the studied farmlands may also explain why overall species richness was highest in agriculture. This is unusual, as homogeneity of agricultural habitats usually leads to a rapid flattening of the species accumulation curve (Sinclair et al. 2002). A meta-analysis (Dunn 2004b) suggests that active tropical agriculture, on average, possesses around 50\% fewer species than benchmark forests. It would appear that we still need to understand variation in the structure of agricultural systems, particularly amongst tropical, developing regions. Clearly, variation in structure offarms 

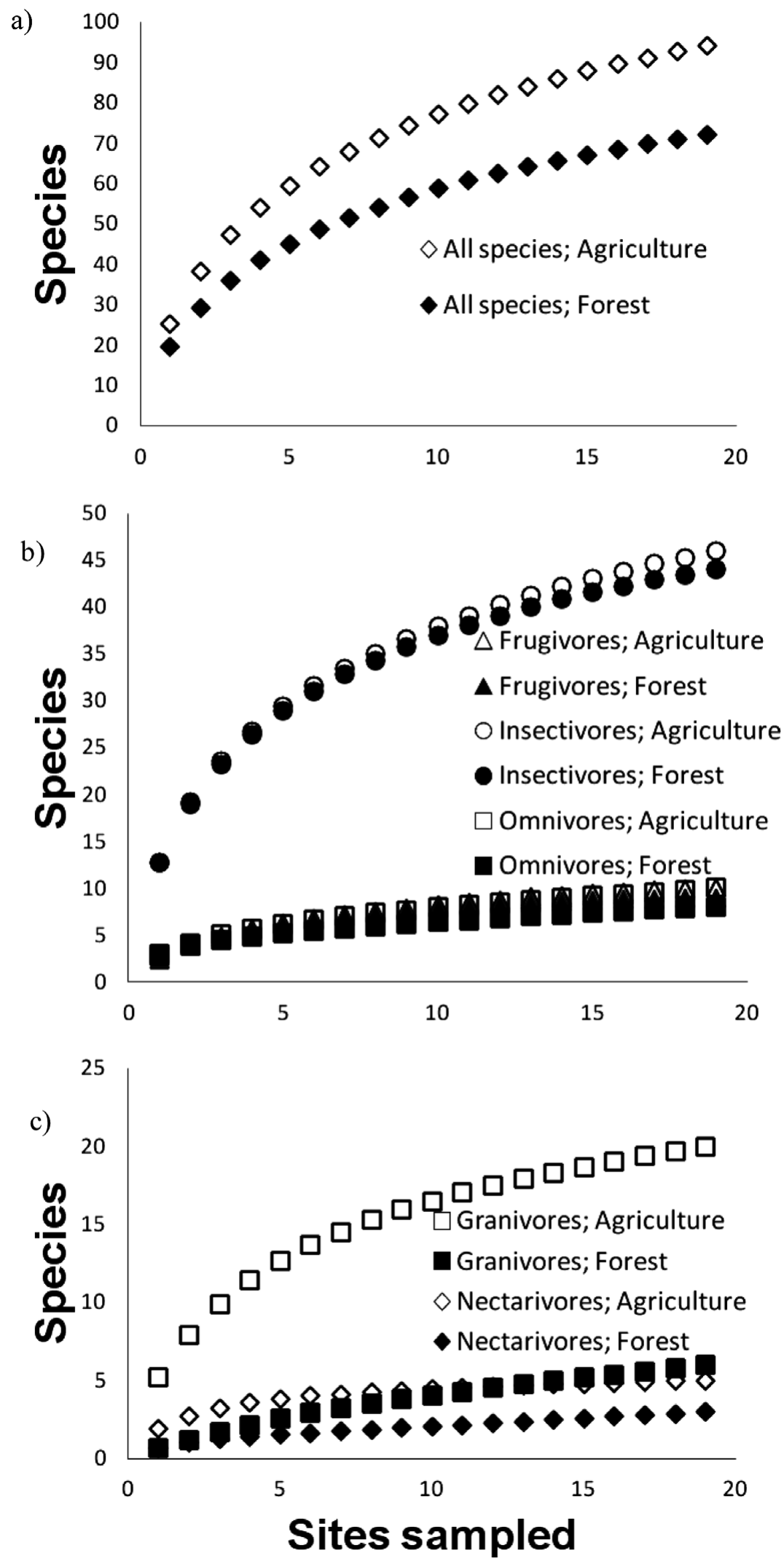

Figure 3. Species accumulation curves for Ethiopian tropical montane bird assemblages in agriculture and forest. Accumulation curves are based on randomisation of samples, with comparisons amongst forest and agricultural plots. Each of the 38 sites was considered as the sample. Accumulation curves for all species combined (a) accumulation curves for frugivores, insectivores and omnivores considered separately (b) accumulation curves for granivores and nectarivores considered separately (c). 
over a landscape can assist in maintaining more species within that landscape. Our results may also suggest that our forests were less species-rich than other forests, due to historical reasons such as bottlenecks in forest cover during climate change epochs or due to the disturbance at edges and not that our agricultural landscape was exceptionally rich (cf. Moreau 1966). Due to the variety of methods used in both survey and analysis, it is difficult to make comprehensive comparisons across published studies, however total observed species in forests in our study is similar to that observed in Cameroon (Waltert et al. 2005), Tanzania (Fjeldså 1999) and Uganda (Owiunji \& Plumptre 1998). It would be interesting to test the hypothesis that the species richness in newly converted farm landscapes is higher if these landscapes are connected to other open landscapes (whether agricultural landscapes or naturally more open areas) than if the conversion is within the forest without such connectivity.

\section{CONCLUSIONS}

Here we have demonstrated that structurally and taxonomically diverse farmlands can have a similar or higher avian diversity compared with forests in all feeding guilds including ostensibly sensitive, bird feeding guilds such as understorey insectivores. The bird species that thrive in the agricultural landscape may be true forest birds that readily adapt to, and monopolize, a new environment or are birds of an evolutionary origin associated with open habitats readily able to colonize recently disturbed sites. The relative roles of local habitat variables and regional species pools remain a fruitful area of research.

\section{ACKNOWLEDGEMENTS}

We thank the many landowners and communities who allowed us access to their land and Teshome Takele for field assistance. The study was supported by a grant from Swedish International Development Cooperation Agency (SIDA) to K.H.

\section{LITERATURE CITED}

ANDRÉN, H. 1994. Effects of habitat fragmentation on birds and mammals in landscapes with different proportions of suitable habitat: a review. Oikos 71:355-366.

ASH, J. \& ATKINS, J. 2009. Birds of Ethiopia and Eritrea: an atlas of distribution. Christopher Helm, London. 463 pp.

CANADAY, C. 1996. Loss of insectivorous birds along a gradient of human impact in Amazonia. Biological Conservation 77:63-77.

CHAPMAN, C. A. \& CHAPMAN, L. J. 1996. Mid-elevation forests: a history of disturbance and regeneration. Pp. 385-400 in
McClanahan, T. R. \& Young, T. P. (eds.). East African ecosystems and their conservation. Oxford University Press, New York.

CLARKE, K. R. 1993. Non-parametric multivariate analysis of changes in community structure. Australian Journal of Ecology 18:117-143.

CLOUGH, Y., DWI PUTRA, D., PITOPANG, R. \& TSCHARNTKE, T. 2009. Local and landscape factors determine functional bird diversity in Indonesian cacao agroforestry. Biological Conservation 142:10321041.

DA SILVA, J. M. C., UHL, C. \& MURRAY, G. 1996. Plant succession, landscape management, and the ecology of frugivorous birds in abandoned Amazonian pastures. Conservation Biology 10:491-503.

DAILY, G. C., EHRLICH, P. R. \& SÁNCHEZ-AZOFEIFA, A. 2001. Countryside biogeography: use of human-dominated habitats by the avifauna of southern Costa Rica. Ecological Applications 11:1-13.

DANIELSEN, F. 1997. Stable environments and fragile communities: does history determine the resilience of avian rain-forest communities to habitat degradation? Biodiversity and Conservation 6:423-433.

DARBYSHIRE, I., LAMB, H. \& UMER, M. 2003. Forest clearance and regrowth in northern Ethiopia during the last 3000 years. The Holocene 13:537-546.

DONALD, P. F., GREEN, R. E. \& HEATH, M. F. 2001. Agricultural intensification and the collapse of Europe's farmland bird populations. Proceedings of the Royal Society of London B 268:25-29.

DUFRÊNE, M. \& LEGENDRE, P. 1997. Species assemblages and indicator species: the need for a flexible asymmetrical approach. Ecological Monographs 67:345-366.

DUNN, R. R. 2004a. Managing the tropical landscape: a comparison of the effects of logging and forest conversion to agriculture on ants, birds, and Lepidoptera. Forest Ecology and Management 191:215-224.

DUNN, R. R. 2004b. Recovery of faunal communities during tropical forest regeneration. Conservation Biology 18:1-8.

DUNNING, J. B. 1992. CRC handbook of avian body masses. CRC Press, Boca Raton. 371 pp.

DYNESIUS, M., HYLANDER, K. \& NILSSON, C. 2009. High resilience of bryophyte assemblages in streamside compared to upland forests. Ecology 90:1042-1054.

FISCHER, J., LINDENMAYER, D., BLOMBERG, S., MONTAGUE-DRAKE, R., FELTON, A. \& STEIN, J. 2007. Functional richness and relative resilience of bird communities in regions with different land use intensities. Ecosystems 10:964-974.

FISCHER, J., STOTT, J. \& LAW, B. S. 2010. The disproportionate value of scattered trees. Biological Conservation 143:1564-1567.

FJELDSÅ, J. 1999. The impact of human forest disturbance on the endemic avifauna of the Udzungwa Mountains, Tanzania. Bird Conservation International 9:47-62.

FLATHER, C. H. 1996. Fitting species-accumulation functions and assessing regional land use impacts on avian diversity. Journal of Biogeography 23:155-168.

FRIIS, I., RASMUSSEN, F. N. \& VOLLESEN, K. 1982. Studies in the flora and vegetation of southwestern Ethiopia. Opera Botanica 63:1-70.

GASTON, K. J. \& BLACKBURN, T. M. 1995. Birds, body size and the threat of extinction. Philosophical Transactions of the Royal Society, London. B. Biological Sciences 347:205-212.

GOVE, A. D., MAJER, J. D. \& RICO-GRAY, V. 2005. Methods of conservation outside of formal reserve systems: the case of ants in 
the seasonally dry tropics of Veracruz, Mexico. Biological Conservation 126:328-338.

GOVE, A. D., HYLANDER, K., NEMOMISSA, S. \& SHIMELIS, A. 2008. Ethiopian coffee cultivation - implications for bird conservation and environmental certification. Conservation Letters 1:208-216.

GRAY, M. A., BALDAUF, S. L., MAYHEW, P. J. \& HILL, J. K. 2007. The response of avian feeding guilds to tropical forest disturbance. Conservation Biology 21:133-141.

GREENBERG, R., BICHIER, P., ANGON, A. C., MACVEAN, C., PEREZ, R. \& CANO, E. 2000. The impact of avian insectivory on arthropods and leaf damage in some Guatemalan coffee plantations. Ecology 81:1750-1755.

HAMILTON, A., TAYLOR, D. \& VOGEL, J. C. 1986. Early forest clearance and environmental degradation in south-west Uganda. Nature 320:164-167.

HARRISON, S. \& CORNELL, H. 2008. Toward a better understanding of the regional causes of local community richness. Ecological Letters 11: 969-979.

HARVEY, C. A., MEDINA, A., SÁNCHEZ, D. M., VÍLCHEZ, S., HERNÁNDEZ, B., SAENZ, J. C., MAES, J. M., CASANOVES, F. \& SINCLAIR, F. L. 2006. Patterns of animal diversity in different forms of tree cover in agricultural landscapes. Ecological Applications 16:1986-1999.

HYLANDER, K. \& NEMOMISSA, S. 2008. Home garden coffee as a repository of epiphyte biodiversity in Ethiopia. Frontiers in Ecology and the Environment 6:524-528.

KARR, J. R. 1976. Within- and between-habitat avian diversity in African and Neotropical lowland habitats. Ecological Monographs 46:457-481.

LUCK, G. W. \& DAILY, G. C. 2003. Tropical countryside bird assemblages: richness, composition, and feeding differ by landscape context. Ecological Applications 13:235-247.

MANNING, A. D., FISCHER, J. \& LINDENMAYER, D. B. 2006. Scattered trees are keystone structures - implications for conservation. Biological Conservation 132:311-321.

MARTIN, E. A., VIANO, M., RATSIMISETRA, L., LALÖ̈, F. \& CARRIÈRE, S. M. 2012. Maintenance of bird functional diversity in a traditional agroecosystem of Madagascar. Agriculture, Ecosystems and Environment 149:1-9.

McCANN, J. C. 1995. People of the plow. An agricultural history of Ethiopia, 1800-1990. University of Wisconsin Press, Madison. 304 pp.

MILLER, A. 2002. Subset selection in regression. Chapman \& Hall, London. $256 \mathrm{pp}$.

MOREAU, R. E. 1966. The bird faunas of Africa and its islands. Academic Press, London. 424 pp.

MULWA, R. K., BÖHNING-GAESE, K. \& SCHLEUNING, M. 2012. High bird species diversity in structurally heterogeneous farmland in western Kenya. Biotropica, in press.
NICHOLS, J. D., BOULINIER, T., HINES, J. E., POLLOCK, K. H. \& SAUER, J. R. 1998. Inference methods for spatial variation in species richness and community composition when not all species are detected. Conservation Biology 12:1390-1398.

OWIUNJI, I. \& PLUMPTRE, A. J. 1998. Bird communities in logged and unlogged compartments in Budongo Forest, Uganda. Forest Ecology and Management 108:115-126.

REDMAN, N., STEVENSON, T. \& FANSHAWE, J. 2009. Birds of the Horn of Africa, Ethiopia, Eritrea, Djibouti, Somalia and Socotra. Christopher Helm, London. 512 pp.

RICKLEFS, R. E. 1987. Community diversity: relative roles of local and regional processes. Science 235: 167-171.

ŞEKERCIOGLU, C. H. 2002a. Forest fragmentation hits insectivorous birds hard. Directions in Science 1:62-64.

ŞEKERCIOGLU, C. H. 2002b. Effects of forestry practices on vegetation structure and bird community of Kibale National Park, Uganda. Biological Conservation 107:229-240.

ŞEKERCIOḠLU, Ç. H., EHRLiCH, P. R., DAILY, G. C., AYGEN, D., GOEHRING, D. \& SANDÍ, R. F. 2002. Disappearance of insectivorous birds from tropical forest fragments. Proceedings of the National Academy of Sciences USA 99:263-267.

ŞEKERCIOĞLU, Ç. H., DAILY, G. C. \& EHRLICH, P. R. 2004. Ecosystem consequences of bird declines. Proceedings of the National Academy of Sciences USA 101:18042-18047.

SINCLAIR, A. R. E., MDUMA, S. A. R. \& ARCESE, P. 2002. Protected areas as biodiversity benchmarks for human impact: agriculture and the Serengeti avifauna. Proceedings of the Royal Society B 269 24012405.

SIRIWARDENA, G. M., CRICK, H. Q. P., BAILLIC, S. R. \& WILSON, J. D. 2000. Agricultural land-use and the spatial distribution of granivorous lowland farmland birds. Ecography 23:702719.

SODHI, N. S., LIOW, L. H. \& BAZZAZ, F. A. 2004. Avian extinctions from tropical and subtropical forests. Annual Review of Ecology, Evolution, and Systematics 35:323-345.

STOUFFER, P. C. \& BIERREGAARD, R. O. 1995. Use of Amazonian forest fragments by understory insectivorous birds. Ecology 76:24292445.

TERBORGH, J. \& WESKE, J. S. 1969. Colonization of secondary habitats by Peruvian birds. Ecology 50:765-782.

TSCHARNTKE, T., SEKERCIOGLU, C. H., DIETSCH, T. V., SODHI, N. S., HOEHN, P. \& TYLIANAKIS, J. M. 2008. Landscape constraints on functional diversity of birds and insects in tropical agroecosystems. Ecology 89:944-951.

WALTERT, M., BOBO, K. S., SAINGE, N. M., FERMON, H. \& MÜHLENBERG, M. 2005. From forest to farmland: habitat effects on afrotropical forest bird diversity. Ecological Applications 15:13511366 . 
Appendix 1. Species occurrences and feeding guild classifications. Nomenclature according to Redman et al. (2009), family placement according to Ash \& Atkins (2009). AFG = Arboreal foliage gleaner; UFG = Understorey foliage gleaner.

\begin{tabular}{|c|c|c|c|c|c|c|}
\hline Common name & Species & Family & $\begin{array}{c}\text { Feeding } \\
\text { guild }\end{array}$ & $\begin{array}{c}\text { Insectivore } \\
\text { subguild }\end{array}$ & $\begin{array}{l}\text { No. sites, } \\
\text { agriculture }\end{array}$ & $\begin{array}{c}\text { No. sites, } \\
\text { forest }\end{array}$ \\
\hline Wattled ibis & Bostrychia carunculata & Threskiornithidae & Insectivore & Terrestrial & 3 & 0 \\
\hline Hadada ibis & Bostrychia hagedash & Threskiornithidae & Insectivore & Terrestrial & 8 & 3 \\
\hline Great sparrowhawk & Accipiter melanoleucus & Acciptridae & Carnivore & $\sim$ & 2 & 2 \\
\hline Augur buzzard & Buteo augur & Acciptridae & Carnivore & $\sim$ & 2 & 1 \\
\hline African harrier-hawk & Polyboroides typus & Acciptridae & Carnivore & $\sim$ & 1 & 0 \\
\hline Chestnut-naped francolin & Pternistis castaneicollis & Phasianidae & Omnivore & $\sim$ & 1 & 1 \\
\hline Red-eyed dove & Streptopelia semitorquata & Columbidae & Granivore & $\sim$ & 15 & 4 \\
\hline Bruce's green pigeon & Treron waalia & Columbidae & Frugivore & $\sim$ & 2 & 1 \\
\hline Blue-spotted wood dove & Turtur afer & Columbidae & Granivore & $\sim$ & 1 & 0 \\
\hline Tambourine dove & Turtur tympanistria & Columbidae & Granivore & $\sim$ & 3 & 4 \\
\hline Black-winged lovebird & Agapornis taranta & Psittacidae & Frugivore & $\sim$ & 10 & 4 \\
\hline Yellow-fronted parrot & Poicephalus flavifrons & Psittacidae & Frugivore & $\sim$ & 0 & 4 \\
\hline White-cheeked turaco & Tauraco leucotis & Musophagidae & Frugivore & $\sim$ & 2 & 17 \\
\hline Coucal sp. & Centropus sp. & Cuculidae & Insectivore & Terrestrial & 4 & 8 \\
\hline African emerald cuckoo & Chrysococcyx cupreus & Cuculidae & Insectivore & AFG & 2 & 2 \\
\hline Klaas's cuckoo & Chrysococcyx klaas & Cuculidae & Insectivore & AFG & 7 & 3 \\
\hline Jacobin cuckoo & Clamator jacobinus & Cuculidae & Insectivore & AFG & 0 & 2 \\
\hline Black cuckoo & Cuculus clamosus & Cuculidae & Insectivore & AFG & 4 & 3 \\
\hline Red-chested cuckoo & Cuculus solitarius & Cuculidae & Insectivore & AFG & 7 & 11 \\
\hline Nyanza swift & Apus niansae & Apodidae & Insectivore & Aerial & 3 & 0 \\
\hline Speckled mousebird & Colius striatus & Coliidae & Frugivore & $\sim$ & 8 & 2 \\
\hline Narina trogon & Apaloderma narina & Trogonidae & Insectivore & AFG & 0 & 6 \\
\hline African pygmy kingfisher & Ceyx pictus & Alcedinidae & Insectivore & Predator-insectivore & 2 & 0 \\
\hline Striped kingfisher & Halcyon chelicuti & Alcedinidae & Insectivore & Pouncer & 4 & 3 \\
\hline Grey-headed kingfisher & Halcyon leucocephala & Alcedinidae & Insectivore & Pouncer & 2 & 0 \\
\hline White-throated bee-eater & Merops albicollis & Meropidae & Insectivore & Sallier & 2 & 1 \\
\hline Silvery-cheeked hornbill & Bycanistes brevis & Bucerotidae & Frugivore & $\sim$ & 6 & 6 \\
\hline Double-toothed barbet & Lybius bidentatus & Ramphastidae & Frugivore & $\sim$ & 2 & 3 \\
\hline Black-billed barbet & Lybius guifsobalito & Ramphastidae & Frugivore & $\sim$ & 1 & 0 \\
\hline Banded barbet & Lybius undatus & Ramphastidae & Frugivore & $\sim$ & 10 & 9 \\
\hline Yellow-fronted tinkerbird & Pogoniulus chrysoconus & Ramphastidae & Omnivore & $\sim$ & 8 & 7 \\
\hline Red-fronted tinkerbird & Pogoniulus pusillus & Ramphastidae & Omnivore & $\sim$ & 3 & 2 \\
\hline Greater honeyguide & Indicator indicator & Indicatoridae & Insectivore & Bees & 1 & 1 \\
\hline Honeyguide sp. & Indicator sp. & Indicatoridae & Insectivore & Bees & 0 & 1 \\
\hline Bearded woodpecker & Dendropicos namaquus & Picidae & Insectivore & Bark gleaner & 3 & 3 \\
\hline Grey-headed woodpecker & Dendropicos spodocephalus & Picidae & Insectivore & Bark gleaner & 1 & 2 \\
\hline Woodpecker sp. & & Picidae & Insectivore & Bark gleaner & 3 & 0 \\
\hline Black cuckoo-shrike & Campephaga flava & Campephagidae & Insectivore & AFG & 1 & 0 \\
\hline Red-shouldered cuckoo-shrike & Campephaga phoenicea & Campephagidae & Insectivore & $\mathrm{AFG}$ & 3 & 1 \\
\hline Grey cuckoo-shrike & Coracina caesia & Campephagidae & Insectivore & $\mathrm{AFG}$ & 0 & 9 \\
\hline Cuckoo-shrike sp. & & Campephagidae & Insectivore & AFG & 0 & 1 \\
\hline Mosque swallow & Cecropis senegalensis & Hirundinidae & Insectivore & Aerial & 1 & 0 \\
\hline Common bulbul & Pycnonotus barbatus & Pycnonotidae & Omnivore & $\sim$ & 17 & 16 \\
\hline African paradise flycatcher & Terpsiphone viridis & Monarchidae & Insectivore & Sallier & 8 & 10 \\
\hline Abyssinian slaty flycatcher & Melaenornis chocolatinus & Muscicapidae & Insectivore & Sallier & 9 & 7 \\
\hline African dusky flycatcher & Muscicapa adusta & Muscicapidae & Insectivore & Sallier & 13 & 3 \\
\hline Black-headed batis & Batis minor & Platysteiridae & Insectivore & Sallier & 4 & 7 \\
\hline Brown-throated wattle-eye & Platysteira cyanea & Platysteiridae & Insectivore & Sallier & 0 & 1 \\
\hline Rüpell's robin-chat & Cossypha semirufa & Turdidae & Insectivore & Terrestrial & 15 & 15 \\
\hline Mountain thrush & Turdus abyssinicus & Turdidae & Insectivore & Terrestrial & 13 & 9 \\
\hline African thrush & Turdus pelios & Turdidae & Insectivore & Terrestrial & 2 & 1 \\
\hline Abyssinian ground-thrush & Zoothera piaggiae & Turdidae & Insectivore & Terrestrial & 1 & 15 \\
\hline Thrush sp. & & Turdidae & Insectivore & Terrestrial & 0 & 2 \\
\hline Cinnamon bracken warbler & Bradypterus cinnатотеиs & Sylviidae & Insectivore & UFG & 1 & 4 \\
\hline Dark-capped yellow warbler & Chloropeta natalensis & Sylviidae & Insectivore & Sallier & 1 & 0 \\
\hline Brown woodland warbler & Phylloscopus umbrovirens & Sylviidae & Insectivore & AFG & 1 & 7 \\
\hline Warbler sp. & & Sylviidae & Insectivore & UFG & 1 & 2 \\
\hline Grey-backed cameroptera & Camaroptera brachyura & Cisticolidae & Insectivore & UFG & 8 & 19 \\
\hline Red-faced cisticola & Cisticola erythrops & Cisticolidae & Insectivore & UFG & 1 & 1 \\
\hline
\end{tabular}


Appendix 1. Continued

\begin{tabular}{|c|c|c|c|c|c|c|}
\hline Common name & Species & Family & $\begin{array}{l}\text { Feeding } \\
\text { guild }\end{array}$ & $\begin{array}{l}\text { Insectivore } \\
\text { subguild }\end{array}$ & $\begin{array}{l}\text { No. sites, } \\
\text { agriculture }\end{array}$ & $\begin{array}{c}\text { No. sites, } \\
\text { forest }\end{array}$ \\
\hline Tawny-flanked prinia & Prinia subflava & Cisticolidae & Insectivore & UFG & 18 & 5 \\
\hline Red-fronted warbler & Urorhipis rufifrons & Cisticolidae & Insectivore & UFG & 12 & 4 \\
\hline African hill babbler & Pseudoalcippe abyssinica & Timaliidae & Insectivore & AFG & 1 & 15 \\
\hline White-rumped babbler & Turdoides leucopygia & Timaliidae & Insectivore & UFG & 9 & 9 \\
\hline Spotted creeper & Salpornis spilonotus & Certhiidae & Insectivore & Bark gleaner & 1 & 2 \\
\hline Montane white-eye & Zosterops poliogastrus & Zosteropidae & Omnivore & $\sim$ & 9 & 10 \\
\hline Yellow white-eye & Zosterops senegalensis & Zosteropidae & Omnivore & $\sim$ & 1 & 0 \\
\hline Scarlet-chested sunbird & Chalcomitra senegalensis & Nectariniidae & Nectarivore & $\sim$ & 3 & 0 \\
\hline Copper sunbird & Cinnyris cupreus & Nectariniidae & Nectarivore & $\sim$ & 8 & 0 \\
\hline Variable sunbird & Cinnyris venustus & Nectariniidae & Nectarivore & $\sim$ & 16 & 10 \\
\hline Collared sunbird & Hedydipna collaris & Nectariniidae & Nectarivore & $\sim$ & 1 & 0 \\
\hline Tacazze sunbird & Nectarinia tacazze & Nectariniidae & Nectarivore & $\sim$ & 8 & 1 \\
\hline Sunbird sp. & & Nectariniidae & Nectarivore & $\sim$ & 0 & 1 \\
\hline Common fiscal & Lanius collaris & Laniidae & Insectivore & Pouncer & 12 & 1 \\
\hline Northern puff-back & Dryoscopus gambensis & Malaconotidae & Insectivore & Predator-insectivore & 4 & 13 \\
\hline Ethiopian boubou & Laniarius aethiopicus & Malaconotidae & Insectivore & UFG & 12 & 19 \\
\hline Grey-headed bush-shrike & Malaconotus blanchoti & Malaconotidae & Insectivore & AFG & 3 & 6 \\
\hline Marsh tchagra & Tchagra minutus & Malaconotidae & Insectivore & Pouncer & 1 & 0 \\
\hline Black-crowned tchagra & Tchagra senegalus & Malaconotidae & Insectivore & Pouncer & 2 & 0 \\
\hline Sulphur-breasted bush-shrike & Telophorus sulfureopectus & Malaconotidae & Insectivore & Pouncer & 0 & 2 \\
\hline Abyssinian oriole/Black-headed oriole & Oriolus monacha/larvatus & Oriolidae & Omnivore & $\sim$ & 8 & 18 \\
\hline Cape rook & Corvus capensis & Corvidae & Omnivore & $\sim$ & 1 & 0 \\
\hline Thick-billed raven & Corvus crassirostris & Corvidae & Omnivore & $\sim$ & 3 & 1 \\
\hline Greater blue-eared starling & Lamprotornis chalybaeus & Sturnidae & Omnivore & $\sim$ & 1 & 0 \\
\hline Red-winged starling & Onychognathus morio & Sturnidae & Omnivore & $\sim$ & 0 & 1 \\
\hline Sharp's starling & Pholia sharpii & Sturnidae & Frugivore & $\sim$ & 1 & 0 \\
\hline Stuhlman's starling & Poeoptera stuhlmanni & Sturnidae & Frugivore & $\sim$ & 2 & 2 \\
\hline Swainson's sparrow & Passer swainsonii & Passeridae & Granivore & $\sim$ & 18 & 1 \\
\hline Red-collared widowbird & Euplectes ardens & Ploceidae & Granivore & $\sim$ & 7 & 0 \\
\hline Fan-tailed widowbird & Euplectes axillaris & Ploceidae & Granivore & $\sim$ & 3 & 0 \\
\hline Northern red bishop & Euplectes franciscanus & Ploceidae & Granivore & $\sim$ & 1 & 0 \\
\hline Black bishop & Euplectes gierowii & Ploceidae & Granivore & $\sim$ & 3 & 0 \\
\hline Yellow-mantled widowbird & Euplectes macroura & Ploceidae & Granivore & $\sim$ & 3 & 0 \\
\hline Baglafecht weaver & Ploceus baglafecht & Ploceidae & Insectivore & AFG & 19 & 2 \\
\hline Village weaver & Ploceus cucullatus & Ploceidae & Insectivore & AFG & 9 & 0 \\
\hline Yellow-bellied waxbill & Coccopygia quartinia & Estrildidae & Granivore & $\sim$ & 1 & 1 \\
\hline Common waxbill & Estrilda astrild & Estrildidae & Granivore & $\sim$ & 1 & 0 \\
\hline Swee waxbill & Estrilda melanotis & Estrildidae & Granivore & $\sim$ & 6 & 1 \\
\hline Red-billed firefinch & Lagonosticta senegala & Estrildidae & Granivore & $\sim$ & 1 & 0 \\
\hline Finch sp. & Lagonosticta sp. & Estrildidae & Granivore & $\sim$ & 1 & 0 \\
\hline Bronze mannakin & Spermestes cucullata & Estrildidae & Granivore & $\sim$ & 9 & 0 \\
\hline Pin-tailed whydah & Vidua macroura & Viduidae & Granivore & $\sim$ & 5 & 1 \\
\hline African citril & Serinus citrinelloides & Fringillidae & Granivore & $\sim$ & 10 & 0 \\
\hline Yellow-fronted canary & Serinus mozambicus & Fringillidae & Granivore & $\sim$ & 3 & 0 \\
\hline Streaky seedeater & Serinus striolatus & Fringillidae & Granivore & $\sim$ & 5 & 0 \\
\hline Brown-rumped seedeater & Serinus tristriatus & Fringillidae & Granivore & $\sim$ & 2 & 0 \\
\hline
\end{tabular}

